\title{
Productivity of Lecturers in International Indexed Journal Publications
}

\author{
Abdul Azis Wahab*, Dedy Achmad Kurniady, Aan Komariah, Amelia Nurusysyifa, Abdul Muhyi \\ Universitas Pendidikan Indonesia \\ Bandung, Indonesia \\ *muthahharah_thahir@upi.edu
}

\begin{abstract}
This study measures the productivity of lecturers at the University of Education of Indonesia in publishing scientific papers or international indexed journals, by calculating the number of publications in reputable international journals, namely Scopus index and WoS/Thomson Reuters index. The method used is qualitative approach, where the research subjects are lecturers at the University of Education of Indonesia. The results of data collection show that the degree of productivity of lecturers at the University of Education of Indonesia in publishing in reputable international journals indexed by Scopus is classified as productive, but for indexation of WoS/Thomson Reuters it is in the less productive category. One of the reasons is because most of the lecturers feel burdened by the high cost of publication.
\end{abstract}

\section{Keywords—lecturer productivity, journal publications}

\section{INTRODUCTION}

The main duty of a lecturer is to implement the Tri Dharma of Higher Education, as mandated in Law of The Republic Indonesia Number 14 Year 2005 concerning Teachers and Lecturers, and Government Regulation of the Republic of Indonesia Number 37 Year 2009 concerning Lecturers. The definition of lecturer as stated in these provisions is an educator with the main task of transforming, developing and disseminating science, technology, and art through education, research and community service.

Tri Dharma of Higher Education is an important part in realizing the seriousness of higher education to carry out a quality education process, guided by the vision and mission which is the direction in achieving the goals it wants to achieve. This applies to all public and private universities. The demand for higher education today is not only to produce graduates who are academically qualified, but all programs and higher education institutions must be able to prove high quality supported by accountability. The factors that determine the level of success and quality of a college include the ability of the lecturers to carry out the duty of the Tri Dharma of Higher Education.

In this connection, the main duty of a lecturer is to carry out the Tri Dharma of Higher Education with a workload of at least equivalent to 12 credits and a maximum of 16 credits in each semester according to academic qualifications. The implementation of this lecturer's main duty needs to be evaluated and reported periodically as a form of accountability for lecturer performance to stakeholders.

A lecturer is required to perform optimally to create results that are beneficial for scientific development and will directly increase the productivity of lecturers who are professional and of high quality. One of the duties of a lecturer in the Tri Dharma of Higher Education is the field of research, this field greatly determines the productivity of the university because the quality and quantity of research produced from a university is one of the key benchmarks in academic achievement and excellence. An assessment of this has also been stated in the higher education accreditation standards and procedures. Higher education institutions that have a reputation as researchbased university are often indicated as having good.

International scientific publication is one of the outputs of research or research and is an indicator of the success of research as part of higher education performance. One of the outputs that must be achieved by higher education institutions towards the World Class University and World Class Research Institution is the number of scientific publications internationally and how much of these publications are used by other academics by citing the writings produced.

Based on the findings of previous research, it is known that the number of research produced by lecturers at the University of Education of Indonesia reaches 300-400 studies each year but the publication is less than 50 , especially for international indexed journals even though the publication of research journals is an accountability and recognition of the results of the research carried out which will enhance the reputation of a research-based university.

This study seeks to analyze the degree of productivity of lecturers at the University of Education of Indonesia in international indexed journals by looking at the number of publications in Scopus indexed journals and WoS/Thomson Reuters indexed journals. 


\section{METHODS}

This study applies with a qualitative approach. Data sources or respondents in this research were lecturers at the University of Education of Indonesia. The research instrument used was a questionnaire containing a number of statements filled in by the lecturer to get an idea of the productivity of lecturers in the University of Education of Indonesia in publishing international indexed journals.

The technique used for data analysis is descriptive analysis. The data analyzed is presented in table form. The processing of the questionnaire data obtained was done by determining the percentage of the questionnaire for each respondent using the following formula:

$$
\mathrm{P}=\frac{\sum J R}{\sum J M} \times 100 \%
$$

\section{Explanation:}

$\mathrm{P} \quad=$ percentage of respondents' answers

$\sum \mathrm{JR}=$ the number of respondents' answers

$\sum \mathrm{JM}=$ the maximum number of answers

Then see how the productivity of lecturers at the University of Education of Indonesia in publishing journals for Scopus indexed and indexed by WoS/Thomson Reuters. Productivity measurement is carried out by grouping productive and less productive categories according to the fulfillment of productivity indicators in international indexed journal publications.

\section{RESULTS AND DisCUSSION}

Productivity in the statement of Liang Gie is the ability to produce a job that is more than the usual standard that has been common [1]. In addition, Riyanto states that productivity is a comparison between the results achieved (output) and the overall resources required (input). Productivity means the comparison between the results achieved and the role of labor in time unity [2].

International scientific publication is one of the outputs of research or research and is an indicator of the success of research as part of higher education performance. One of the outputs that must be achieved by higher education institutions towards the World Class University and World Class Research Institution is the number of scientific publications internationally and how many of these publications are used by other academics by citing the writings produced.

Explained related to the meaning of a scientific journal that: a scholarly journal is a periodical that contains articles written by experts in a particular field of study. The articles are intended to be read by the experts or students of the field and are usually much more sophisticated and advanced that the articles found in popular magazines. Many instructors assign research papers or projects that require student to use articles in scholarly journals [3].

In this statement, it can be seen that a scientific journal contains articles written by experts in their fields. The quality of the journal written is guaranteed if it has been indexed by an indexing agency, two of which are Scopus and Thomson Reuters. This index is integrated into the Web of Science, so that this index is used in Web metrics ranking.

Based on the results of the questionnaire analysis given to the respondents, the productivity of lecturers can be calculated in the publication of international indexed journals. Scopus indexed international journal publications by lecturers at the University of Education of Indonesia are presented in the figure 1.

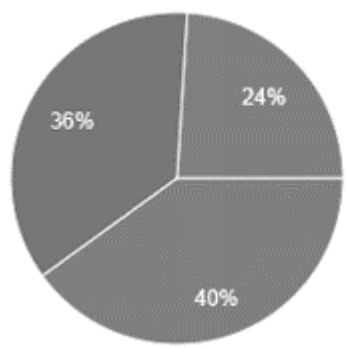

Fig. 1. Diagram of the data processing of international journal publications indexed by Scopus in one academic year.

The diagram in the figure above shows that in one academic year, as many as $24 \%$ of the lecturers who were questionnaire respondents stated that more than once a year, they published international journals indexed by Scopus. Meanwhile, another 36\% publish once a year. However, almost half of them, as many as $40 \%$ of the lecturers, did not produce a single Scopus indexed publication journal.

The second data produced is the average productivity of the journal publication indexed by WoS/Thomson Reuters which is presented in the figure 2 .

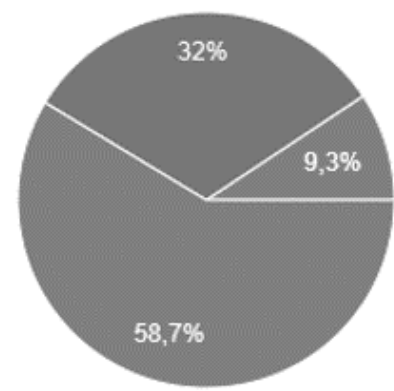

Fig. 2. Diagram of the data processing international journal publications indexed by WoS/Thomson Reuters in one academic year.

The diagram in the figure above shows that in one academic year, as many as $9.3 \%$ of the lecturers who were questionnaire respondents stated that more than once a year, they published international journals indexed by WoS/Thomson Reuters. Meanwhile, another 32\% publish once 
a year. In addition, as many as $58.7 \%$ of the lecturers did not produce a single journal publication indexed by WoS/Thomson Reuters.

To determine the degree of productivity, expressed by the National Productivity Council in Tjiptoheriyanto and Nagib [4] that there are two formulations about productivity. First, productivity is relatively abstract and involves a value system, where productivity is a mental attitude that sees tomorrow as better than today. Second, a technical definition, namely the ratio of the desired output to all the inputs used to produce the output. In this study, the degree of productivity was determined based on the number of international indexed journals published in each academic year.

Referring to the main duty of the lecturer is to carry out the Tri Dharma of Higher Education, as mandated in The Law of Republic Indonesia Number 14 Year 2005 concerning Teachers and Lecturers, and Government Regulation of the Republic Indonesia Number 37 Year 2009 concerning Lecturers, one of the fields in the Tri Dharma of Higher Education is research and scientific work.

One indicator of lecturer productivity in implementing the Tri Dharma of Higher Education in the field of research and scientific work is that each lecturer in one academic year produces at least one international indexed journal.

Based on these indicators, the degree of lecturer productivity can be grouped into productive and less productive categories. The results of data processing based on these indicators also found the data presented in the table 1 .

TABLE I. THE DEGREE OF LECTURER PRODUCTIVITY IN INTERNATIONAL INDEXED JOURNAL PUBLICATIONS

\begin{tabular}{|l|l|l|l|l|}
\hline \multirow{2}{*}{$\begin{array}{c}\text { Productivity } \\
\text { Indicators }\end{array}$} & $\begin{array}{c}\text { Exceed } \\
\text { the } \\
\text { indicator }\end{array}$ & $\begin{array}{c}\text { Fulfill } \\
\text { the } \\
\text { indicator }\end{array}$ & $\begin{array}{c}\text { Does not } \\
\text { fulfill the } \\
\text { indicator }\end{array}$ & Explanation \\
\hline $\begin{array}{l}\text { Scopus indexed } \\
\text { journal } \\
\text { publications }\end{array}$ & $24 \%$ & $36 \%$ & $40 \%$ & Productive \\
\hline $\begin{array}{l}\text { WoS/Thomson } \\
\text { Reuters indexed } \\
\text { journal } \\
\text { publications }\end{array}$ & $9,3 \%$ & $32 \%$ & $58,7 \%$ & $\begin{array}{l}\text { Less } \\
\text { Productive }\end{array}$ \\
\hline $\begin{array}{l}* \text { Explanation based on the addition of the percentage figures that fulfill } \\
\text { and exceed the indicators with the size provisions; } \\
\text { productive, 51-100\% = Productive }\end{array}$ \\
\begin{tabular}{l}
\hline \\
prodive Less
\end{tabular} \\
\hline
\end{tabular}

The data shows that the Scopus indexed journal publications are at a productive level because the number of productive lecturers who fulfill the indicators is $60 \%$. Meanwhile, the journal publications indexed by WoS/Thomson Reuters are in a less productive degree because more than $50 \%$ of the lecturers do not do a single publication in one academic year.

In productivity, there are at least 2 (two) aspects that are important to consider in analyzing employee productivity levels, namely internal and external. Internal employee factors are factors that come from employees and can occur because of natural elements (talents) and natural books (learning and training). While external factors are factors that come from outside the ability of the employee, but really determine how successful a job. For example, the use of technology and professional management Tjiptoherijanto and Nagib [4]. The relationship between human factors and the organization's internal environment on productivity can be seen in the figure 3.

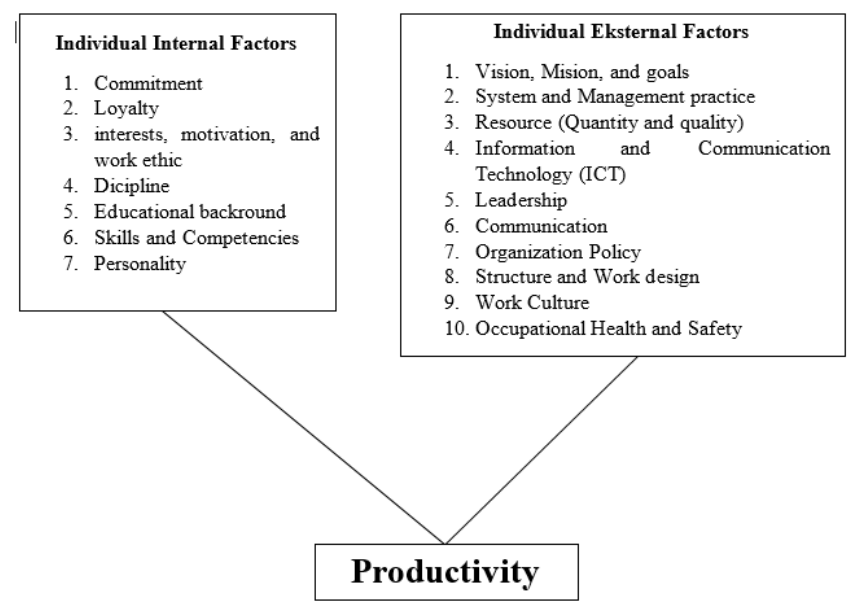

Fig. 3. Factors that affect productivity according to Yuniarsih and Suwatno [5].

Based on the results of the distribution of questionnaires given to 75 respondent lecturers, two things were explored that could affect the productivity of lecturers in carrying out international journal publications, namely related to policies and publication barriers with regard to journal publication costs. The data obtained can be seen in Figure 4.

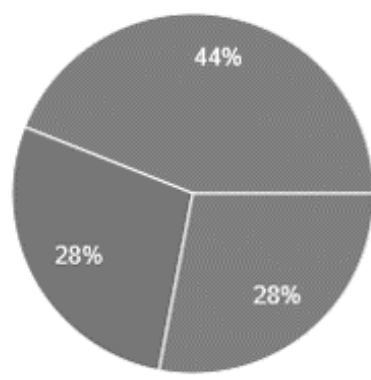

Fig. 4. Diagram of statement data processing results related to the existence of scientific publication policies.

The diagram above is the result of the processing of respondents 'statements regarding lecturers' attitudes towards policies regarding the obligation to carry out scientific publications in international indexed journals. As many as $44 \%$ of lecturers disagreed with the policy being a burden, $28 \%$ also felt less agreeable. However, there are $28 \%$ of respondent lecturers who stated that they felt that the policy of scientific publications in international indexed journals was a burdensome policy. 
Organizational policy is one of the external factors that affect the degree of productivity produced by lecturers. The results of the research data indicate that $72 \%$ of the lecturers feel less and even do not agree if the policy is burdensome, in fact the policy is one of the factors that affect the resulting productivity.

Productivity in publishing international indexed journals is certainly influenced by the cost factor. Data found in the field related to this can be seen in Figure 5.

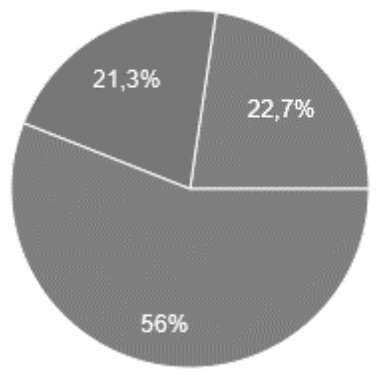

Fig. 5. The diagram of statement data processing results related to the high cost burden of scientific publications.

The results of the distribution of the questionnaires outlined in the diagram show that as many as $44 \%$ of the lecturers are less and even do not agree that high publication costs are a burden. However, 56\% who are more dominant stated that they agree that they feel burdened by the high cost of publication in international journals. Through these data, it is illustrated that one of the causes for the lack of lecturer productivity in carrying out scientific publications or international indexed journals, one of which is the high cost of publication.

\section{CONCLUSION}

Based on the results of the research, it shows that the degree of productivity of lecturers in the University of Educationof Indonesia in publishing international journals indexed by Scopus is productive. Meanwhile, international journal publications indexed by WoS/Thomson Reuters are less productive. The factor that was found to influence the lack of productivity was the relatively high cost of publishing international journals. In addition, the factor that influences lecturers' productivity in publishing international indexed journals is the existence of policies related to the obligation to carry out international indexed scientific publications provided by universities.

\section{REFERENCES}

[1] L. Gie, Ensiklopedia Administrasi. Jakarta: Ghalia Indonesia, 1987.

[2] J. Riyanto, Produktivitas dan Tenaga Kerja. Jakarta: SIUP, 1986.

[3] Santiago Canyon College, "Idenrifying Primary and Secondary Research," $2017 . \quad$ [Online]. Retrieved from: https://sccollege.edu/Library/Pages/primarysources.aspx

[4] P. Tjiptoheriyanto and L. Nagib, Pengembangan SDM: Diantara Peluang dan Tantangan. Jakarta LIPI Press, 2008.

[5] T. Yuniarsih and S. Suwatno, Manajemen Sumber Daya Manusia: Teori, Aplikasi, dan Isu Penelitian. Bandung: Alfabeta, 2009. 